\title{
WATER TEMPERATURE EFFECTS ON GROWTH, FEED UTILIZATION AND SURVIVAL OF BLACK PACU (Colossoma macropomum) FINGERLINGS
}

\author{
Fred CHU-KOO', Paul M. STEWART ${ }^{2}$, Jorge L. BABILONIA ${ }^{3}$, Carmen GARCÍA-DÁVILA', Jesse \\ TRUSHENSKI ${ }^{4}$, Christopher C. KOHLER ${ }^{4}$ \\ 1 Instituto de Investigaciones de la Amazonía Peruana - IIAP. Programa AQUAREC. Carretera lquitos - Nauta Km 4.5. San Juan \\ Bautista, Loreto, Perú. E-mailfchuk20@gmail.com \\ 2 Troy University. Biological and Environmental Sciences. 210F McCall (MSCX). Troy, Alabama, USA. \\ 3 Universidad Nacional de la Amazonía Peruana - UNAP. Escuela de Post-grado. Maestría en Acuicultura. \\ 4 Southern Illinois University Carbondale. Fisheries and Illinois Aquaculture Center. 1125 Lincoln Drive, Office 173. Life Science II. \\ 62901. Carbondale, Illinois, USA.
}

\begin{abstract}
Ectothermic organisms normally live within a specific interval of thermal variation and life outside of that interval can be extremely difficult or lethal. Aquacultural use of black pacu Colossoma macropomum has expanded to diverse areas with various climatic conditions. In the past few years, practical aquafeeds have been evaluated striving to improve the performance of Amazonian fish, but there is little information regarding environmental effects on black pacu growth, feed intake and utilization. This lack of information, limits the ability to optimize the dietary intake and feed utilization, and makes it difficult to plan for future temperature changes. The goal of this study was to evaluate and compare black pacu fingerling growth, feed utilization and survival when reared at three water temperatures: $27.5,30$ and $32.5^{\circ} \mathrm{C}$. Ninety fingerlings $(1.38 \pm 0.03 \mathrm{~g}$ mean total weight) were distributed in groups of 10 individuals and placed into nine 30-L volume fiberglass tanks. Fishes were submitted to a 7-day acclimation period before initiating the 21-day rearing trial. Fish reared at $30^{\circ} \mathrm{C}$ demonstrated significantly higher final body weight, body weight gain, specific growth rate, feed conversion ratio, and protein efficiency ratio levels than fish reared at 27.5 and $32.5^{\circ} \mathrm{C}(\mathrm{P}<0.05)$. No significant differences $(\mathrm{P}>0.05)$, were recorded for feed intake, protein intake, or condition factor. This study suggests temperature increase may impair the ability of black pacu to utilize feed and culturing at water temperatures above $30^{\circ} \mathrm{C}$ may be limiting for this fish.
\end{abstract}

KEYWORDS: Aquaculture of black pacu, temperature, growth, feed utilization, survival.

\section{EFECTOS DE LA TEMPERATURA DEL AGUA SOBRE EL CRECIMIENTO, LA UTILIZACIÓN DE ALIMENTOS Y SUPERVIVENCIA DE ALEVINOS DE GAMITANA (Colossoma macropomum) RESUMEN}

Los organismos ectotérmicos viven normalmente dentro de un rango específico de variación térmica, tanto que la vida fuera de ese rango puede ser difícil o letal. El cultivo de la gamitana Colossoma macropomum en el Perú, se ha expandido hacia áreas con distintas condiciones climáticas. En acuicultura, recientemente se han evaluado nuevos insumos y dietas balanceadas para este pez, pero existe poca información referente al efecto de las variables medioambientales sobre el crecimiento, alimentación y utilización de los alimentos en esta especie. Este vacío de información, limita nuestra habilidad para optimizar la ingestión y utilización apropiada de los alimentos en $C$. macropomum y dificulta la planificación ante escenarios futuros de cambios de temperatura. El objetivo del presente estudio fue evaluar y comparar el crecimiento, la utilización de alimentos y la sobrevivencia de alevinos de gamitana criadas en tres temperaturas: $27.5,30$ y $32.5^{\circ} \mathrm{C}$. Noventa alevinos (peso promedio de $1.38 \pm 0.03 \mathrm{~g}$ ) fueron distribuidos en grupos de 10 ejemplares y colocados dentro de nueve tanques de fibra de vidrio de $30 \mathrm{~L}$ de volumen. Los peces fueron sometidos a un periodo de aclimatación de 7 días previo al inicio del periodo experimental que tuvo una duración de 21 días. Los peces criados a $30^{\circ} \mathrm{C}$ tuvieron niveles de peso final, ganancia de peso, tasa específica de crecimiento, tasa de conversión alimenticia y tasa de eficiencia proteica significativamente mejores que los peces de los tratamientos térmicos 27.5 y $32.5^{\circ} \mathrm{C}(\mathrm{P}<0.05)$. No se reportaron diferencias significativas en lo referente a la ingesta de alimento, ingesta de proteínas y factor de condición. El estudio sugiere que un incremento de temperatura puede afectar la habilidad de la gamitana de utilizar adecuadamente sus alimentos y que el cultivo de este pez a temperaturas mayores a $30^{\circ} \mathrm{C}$ puede ser limitante para la especie.

PALABRAS CLAVE: Acuicultura de gamitana, temperatura, crecimiento, utilización de alimentos, sobrevivencia. 


\section{INTRODUCTION}

Aquaculture development in South America is relatively new and mostly dedicated to introducing species such as salmonids (e.g., Chile), exotic prawns, shrimps and tilapia strains (e.g., Brazil, Ecuador and Peru). The black pacu (Colossoma macropomum) is a neotropical fish with high potential for aquacultural use whose farming has rapidly expanded along the Amazonian countries (Lochmann et al., 2009; Núñez, 2009). This fish is commercially relevant in Peru, where some advances focused on nutritional and reproductive aspects have been made (Alcántara et al., 2001; Dabrowski et al., 2003; Lochmann et al., 2009; Dañino et al., 2011ab).

Peruvian statistics show a total production of 1200 MT fish in 2011 (PRODUCE, 2012), a significant increase since production levels were only about 15.6 MT in year 2002. However, there are serious suspicions about official data underestimating the actual yields since pacu culture has rapidly spread to most Andean/Amazonian departments (equivalent to states, e.g., Cuzco, Huánuco, Junín, etc.) in the last five years where no official data are collected (Chu-Koo \& Alcántara, 2009). Tello (2011) estimates an overall aquaculture production of about 3,000 MT of pacu/yr in the Peruvian Amazon.

As aquacultural use of black pacu has expanded to diverse areas with various climatic conditions, several practical aquafeeds have been evaluated in the past few years to improve the growth performance of this fish, in both commercial and/or small-scale operations (Campos-Baca \& Kohler, 2005; Casado et al., 2009; Lochmann et al., 2009). To date, there is currently little information available related to environmental effects on black pacu growth through effects on fish physiology and feed intake and utilization. This lack of information limits the ability to optimize the commercial diets that are currently available and makes it difficult to plan for future temperature changes. The goals of this study were to evaluate and compare black pacu fingerling growth, feed utilization and survival when reared at three water temperatures: $27.5,30$ and $32.5^{\circ} \mathrm{C}$

\section{METHODS}

\section{FISH}

Ninety, 45-day old fingerlings $(1.38 \pm 0.03 \mathrm{~g}$ mean initial total weight) from a single pair of broods were used in this study. Fishes were obtained by artificial reproduction using carp pituitary extract (Argent Chemical Laboratories, Inc., Redmond Washington, USA) in two dosages ( $6 \mathrm{mg} / \mathrm{kg}$ of fish body weight in females and $1 \mathrm{mg} / \mathrm{kg}$ in males). Black pacu fingerlings were reared in hatchery facilities at the Instituto de Investigaciones de la Amazonía Peruana in Iquitos, Peru, in a temperature-controlled recirculating system $\left(26.5^{\circ} \mathrm{C}\right)$ and fed an extruded diet (PURIGAMITANA ${ }^{\circledR}$ ) manufactured by Purina, Inc. (Lima, Peru). The experiment phase lasted for 21 days.

\section{FEEDING TRIAL}

The experiment was performed in three recirculating systems each with $1,120 \mathrm{~L}$ capacity and the water temperature gradually adjusted from $26.5^{\circ} \mathrm{C}$ over approximately $30 \mathrm{~h}$ to the intended experimental temperatures. A set of three experimental temperature groups were set up in triplicate as follows: $27.5,30$, and $32.5^{\circ} \mathrm{C}(3 \times 3=9$ tanks $)$. Ten fish were randomly assigned to each tank (for a total of 90 used in the experiment). Total water volume of each tank was maintained at $30 \mathrm{~L}$, and the water flow was regulated to allow a continuous water exchange at a rate of 1 $\mathrm{L} / \mathrm{min}$. In addition, the water was aerated with an airstone at a moderate rate in each tank. Natural photoperiod was maintained in the laboratory during the experimental period.

During the experiment, fish were fed $7 \%$ of their initial body weight twice a day with a commercially extruded diet (PURIGAMITANA ${ }^{\circledR}$, Purina Inc. Lima, Peru). According to the manufacturer's specifications, the diet contained $28 \%$ crude protein, $5 \%$ crude lipid, $14 \%$ ash, $3 \%$ of crude fiber, $11 \%$ moisture and $39 \%$ carbohydrate as delivered. Daily feed supply was recorded for each tank, and uneaten food was removed by siphoning twice per day, dried and weighed in order to estimate the actual food intake by all the fish in each tank (factoring in the moisture content of the original food supply). Fish feces were removed by siphoning once per day two hours post-feeding.

\section{WATER QUALITY}

Water temperature, dissolved oxygen, and $\mathrm{pH}$ values were measured two times per day using an YSI Model 55 Oxymeter ${ }^{\circledR}$ (USA) and a WTW 330i ${ }^{\circledR}$ pH meter (Germany), respectively. Nitrite, ammonia, and total alkalinity values were measured weekly, using a AQ-2 Freshwater Aquaculture $\mathrm{Kit} \circledast$, manufactured by LaMotte (Maryland, USA).

\section{FISH GROWTH, FEED UTILIZATION AND SURVIVAL}

Individual initial body weight (IBW) was measured at the beginning of the experiment on an A\&D Company, Ltd., GF- $400 \circledR$ scale $( \pm 0.01 \mathrm{~g})$. At the end, individual 
final body weight (FBW); body weight gain (BWG = final body weight - initial body weight); specific growth rate $(\mathrm{SGR}=100 \mathrm{x}[\ln$ final body weight $(\mathrm{g})-\ln$ initial body weight $(\mathrm{g})] \mathrm{x}$ time ${ }^{-1}$ of rearing (days)); feed conversion ratio $(\mathrm{FCR}=$ total food consumed $(\mathrm{g}$ as-dry matter) $\mathrm{x}$ [final fish biomass $(\mathrm{g})$ - initial fish biomass $\left.(\mathrm{g})]^{-1}\right)$; feed intake ( $\mathrm{FI}=$ weight of feed consumed); protein intake (PI = weight of dietary crude protein consumed); protein efficiency ratio $(\mathrm{PER}=$ [final body weight $(\mathrm{g})$ - initial body weight $(\mathrm{g})]$ $\mathrm{x}$ protein intake $^{-1}(\mathrm{~g})$ ); and survival rate $(\mathrm{S})$ were evaluated.

\section{STATISTICAL ANALYSIS}

Data were analyzed with JMP IN v 4.0.4® statistical software, using one-way ANOVA and data were expressed as the mean \pm standard error (SEM) of three replicates $(\mathrm{N}=3)$. Multiple comparisons of means were performed using Tukey's HSD test only when significant differences were found by ANOVA. Statements of statistical significance were based on a probability of $P<0.05$.

\section{RESULTS}

\section{WATER QUALITY}

Water quality parameters, except for temperature, remained relatively consistent among treatments during the experiment and value ranges were considered adequate for black pacu culture (Table 1). Although alkalinity values could be considered low for temperate fish culture, these are considered as normal for lowland Amazonian aquacultural waters. Fish growth, feed utilization and survival

Initial body weight (weights recorded at the beginning of the experiment), were not significantly different among treatments (Table 2). After 21 days of feeding, treatments demonstrated significantly different values for FBW, BWG, \%BWG, SGR, FCR, and PER (see Table 5.2 for reporting of significance levels). FI and PI were not significantly different among treatments at the end of the experiment. The feed conversion ratio was highest in the $27.5^{\circ} \mathrm{C}$ treatment, while all other significantly different parameters were highest in the $30{ }^{\circ} \mathrm{C}$ treatment, followed by the $32.5^{\circ} \mathrm{C}$ treatment. No fish mortality was recorded during the experiment.

Tabla 1. Water quality values recorded weekly during 21 days of rearing black pacu (Colossoma macropomum) fingerlings in a water recirculation system. Means and standard deviation of three replicates (tanks).

\begin{tabular}{|c|c|c|c|c|}
\hline ÍNDICES & $\mathbf{N}$ & $\mathrm{T} 1\left(27.5^{\circ} \mathrm{C}\right)$ & $\mathrm{T} 2\left(30^{\circ} \mathrm{C}\right)$ & $\mathrm{T} 3\left(32.5^{\circ} \mathrm{C}\right)$ \\
\hline Temperature $\left({ }^{\circ} \mathrm{C}\right)$ & 3 & $27.5 \pm 0.3$ & $29.9 \pm 0.3$ & $32.6 \pm 0.3$ \\
\hline Dissolved Oxygen (mg/L) & 3 & $5.1 \pm 0.9$ & $4.8 \pm 0.5$ & $4.6 \pm 0.9$ \\
\hline $\mathrm{pH}$ & 3 & $6.8 \pm 0.2$ & $6.9 \pm 0.2$ & $6.9 \pm 0.21$ \\
\hline Total Alkalinity (mg/L) & 3 & $21.0 \pm 4.8$ & $21.8 \pm 2.4$ & $9.3 \pm 3.4$ \\
\hline Nitrite (mg/L) & 3 & $<0.05$ & $<0.05$ & $<0.05$ \\
\hline Ammonia (mg/L) & 3 & $<0.20$ & $<0.20$ & $<0.20$ \\
\hline
\end{tabular}


Tabla 2. Growth, feed utilization and survival of black pacu (Colossoma macropomum) fingerlings reared in three water temperature treatments over a 3-wk growth trial. Means and standard deviation of three replicates and values within the same l ine with different letters were significantly different $(\mathrm{P}<0.05)$.

\begin{tabular}{|c|c|c|c|c|}
\hline \multirow{2}{*}{ PARAMETERS } & \multicolumn{4}{|c|}{ WATER TEMPERATURE TREATMENTS } \\
\hline & $\mathrm{T} 1\left(27.5^{\circ} \mathrm{C}\right)$ & $\mathrm{T} 2\left(30^{\circ} \mathrm{C}\right)$ & T3 $\left(32.5^{\circ} \mathrm{C}\right)$ & P Value \\
\hline IBW (g) & $1.36 \pm 0.04$ & $1.39 \pm 0.05$ & $1.43 \pm 0.04$ & 0.2720 \\
\hline FBW (g) & $2.97 \pm 0.14^{\mathrm{a}}$ & $4.05 \pm 0.08^{b}$ & $3.58 \pm 0.10^{c}$ & $<0.0001$ \\
\hline BWG (g) & $1.60 \pm 0.10^{\mathrm{a}}$ & $2.67 \pm 0.11^{b}$ & $2.15 \pm 0.07^{c}$ & $<0.0001$ \\
\hline SGR $(\%$ BW/d) & $3.70 \pm 0.18^{a}$ & $5.10 \pm 0.22^{b}$ & $4.38 \pm 0.09^{c}$ & $<0.0001$ \\
\hline $\mathrm{Fl}(\mathrm{g})$ & $17.29 \pm 0.64$ & $18.03 \pm 0.37$ & $17.67 \pm 0.28$ & 0.2292 \\
\hline $\mathrm{Pl}(\mathrm{g})$ & $4.84 \pm 0.18$ & $5.05 \pm 0.10$ & $4.95 \pm 0.08$ & 0.2292 \\
\hline FCR & $1.08 \pm 0.04^{\mathrm{a}}$ & $0.69 \pm 0.03^{b}$ & $0.82 \pm 0.05^{c}$ & $<0.0001$ \\
\hline PER & $6.13 \pm 0.09^{\mathrm{a}}$ & $8.04 \pm 0.03^{b}$ & $7.23 \pm 0.08^{c}$ & $<0.0001$ \\
\hline Survival (\%) & \multicolumn{4}{|c|}{100} \\
\hline
\end{tabular}

\section{DISCUSSION}

Results of this study demonstrated that the greatest growth and most efficient feed utilization for black pacu fingerlings were obtained at $30^{\circ} \mathrm{C}$. Final body weight was highest at $30{ }^{\circ} \mathrm{C}$, followed by a significantly reduced weight at the lower and higher temperatures. Since SGR and FCR were also significantly higher in fish reared at $30^{\circ} \mathrm{C}$, it may be an indication that the optimal rearing temperature for black pacu would be close to this temperature. However, this study has a procedural limitation that does not allow me to strongly conclude $30^{\circ} \mathrm{C}$ is the optimal culture temperature since I fed the fish at a fixed rate ( $3 \%$ body weight/day), therefore, limiting fish daily feed intake. Several studies suggest fish reared at higher temperatures dramatically increase feed intake (Okamoto et al., 2006; Sun \& Chen, 2009). Hence, feeding fish to satiation would be the best procedure to be employed in that particular case. Satiation feeding is the maximum amount of feed that an organism can consume in a given period of time based on its size, water quality and temperature (Jobling, 1994; Robertson et al., 1998). As I applied a fixed feeding rate of $3 \%$ body weight/day it is not really surprising that feed intake and consequently protein intake were not significantly different among treatments at the end of the present study.

Several studies addressed the influence of feeding rate on black pacu growth. For instance, Silva et al. (2007) found that juvenile black pacu fed $10 \% \mathrm{BW} /$ day divided in 3 meals/day, presented higher growth rates in weight and specific growth rate, when compared to fish fed 5\% BW/day. An experiment conducted by Borghetti \& Canzi (1993) studied the influence of water temperature and feeding rate $(1,3$ and $5 \%)$ on the growth of juvenile $(94.6 \pm 5.9 \mathrm{~g})$ pacu (Piaractus mesopotamicus), a closely-related species to black pacu. They found that both variables resulted in significant differences in weight gain and FCR, showing that within the temperature intervals of $19-20^{\circ} \mathrm{C}, 24^{\circ} \mathrm{C}$ and $27-30^{\circ} \mathrm{C}$, the feeding rates of 1,3 and $5 \% \mathrm{BW} /$ day, respectively, yielded the best outcomes in this species.

Kubitza (2000) reported similar results for tilapia (Oreochromis niloticus) showing negative impacts on growth above $32{ }^{\circ} \mathrm{C}$ and below $27^{\circ} \mathrm{C}$ due to a drastic reduction in feed intake. Similarly, Okamoto et al. (2006) reported in mullet (Mugil cephalus) best growth and FCR performances at $30^{\circ} \mathrm{C}$. Meanwhile, Das et al. (2005) recorded highest body weight gain, SGR and lowest FCR for rohu (Labeo rohita) at temperatures between 31 and $33{ }^{\circ} \mathrm{C}$. A 2-wk study conducted by Sun \& Chen (2009), assessing the effects of ration level and water temperature $(21,27$ and $33{ }^{\circ} \mathrm{C}$ ), on growth, fecal production and nitrogenous excretion of 10-g cobia (Rachycentron canadum), reported a positive increase in maximal, optimal, and maintenance ration, fecal production and nitrogenous excretion with increasing ration and temperatures $\left(21\right.$ to $\left.33^{\circ} \mathrm{C}\right)$. Moreover, Petry et al. (2007) investigated the effect of temperature on prey consumption and growth of Amazon fish trahira (Hoplias aff. malabaricus), reporting that prey consumption differed significantly among thermal treatments since trahiras at $18^{\circ} \mathrm{C}$ consumed significantly fewer preys than those at $30^{\circ} \mathrm{C}$.

Poikilothermic organisms have a thermal interval within which they reach their best growth potential 
(Piedras et al., 2004). That fact may be directly related to the enzymatic activity involved in the digestive physiology of the fish. In this investigation, black pacu's lowered body weight gain and FCR observed at $32.5^{\circ} \mathrm{C}$ may suggest that optimal enzymatic thermal ranges are lower than $32.5^{\circ} \mathrm{C}$ or perhaps fishes were not getting enough feed as it was restricted at a fixed feeding rate of $3 \%$ of BW/day. No enzymatic trial was conducted in this study, but there are examples that clearly support this assumption (e.g., in Nile tilapia; De Souza et al., 2007). As environmental temperatures increase up to a thermal optimum, biochemical reaction rates increase as well, resulting in faster metabolic rates (Miller et al., 1988; Sogard \& Olla, 2002; Hochachka \& Somero, 2002). As said in my study, a significant increase in feed intake among treatments was not observed, instead, significant differences in the FCR level of black pacu fingerlings (highest at $30^{\circ} \mathrm{C}$ ) occurred.

Previous studies revealed how temperature can affect growth and feed utilization in fish. Pérez-Casanova et al. (2009) tested how dietary protein and lipid levels and water temperature affected the SGR, food consumption (FC), and gross conversion efficiency (GCE) of juvenile Atlantic cod (Gadus morhua) and haddock (Melanogrammus aeglefinus). They found low rearing temperature $\left(2^{\circ} \mathrm{C}\right)$ has a negative impact on FC, SGR, and GE. Another study conducted by Lee and Pham (2011), assessed digestibility of diets containing either $\alpha$-potato starch (A-PS), $\beta$-potato starch (B-PS), $\beta$-corn starch (B-CS) or dextrin (DEX) as dietary carbohydrate energy for juvenile and grower rockfish (Sebastes schlegeli) reared at $13^{\circ} \mathrm{C}$ and $20^{\circ} \mathrm{C}$, and found that water temperatures, significantly affected digestibility in this fish.

The superior performance of black pacu reared at 30 ${ }^{\circ} \mathrm{C}$, compared to the lower and higher temperatures tested, suggest that rearing fingerlings at temperatures varying from the optimal may affect their metabolic rate. Similar outcomes have been reported in the Indian major carp Labeo rohita (Murugaian et al., 2008), and African catfish Clarias fuscus (Anderson \& Fast, 2008). Black pacu can be regarded as an eurythermal fish, which means that it can endure living even in extreme temperature (as low as $23^{\circ} \mathrm{C}$ as high as $33{ }^{\circ} \mathrm{C}$, personal observations) but optimal thermal ranges for this species as observed in the current study seemed to vary between 29 and $30^{\circ} \mathrm{C}$. Unfortunately, there are no previous studies demonstrating how water temperature may affect black pacu growth over an extended time, as it exists for other fishes (Ayala, 1999; Kubitza, 2000; Arizcun et al., 2002; Piedras et al., 2004).

Oyugi et al.(2012) revealed a strong thermal influence on foraging and growth in juvenile common carp
Cyprinus carpio (90-105 mm) between 16 and $28^{\circ} \mathrm{C}$. They showed optimal feeding rates occurred at temperatures $>20^{\circ} \mathrm{C}$ with SGR being depressed at 16 and $28^{\circ} \mathrm{C}$ when compared to those achieved at 20 and $24^{\circ} \mathrm{C}$. These outcomes suggest an increase in foraging and growth of common carp according to a thermal gradient that were maximal between 20 and $24^{\circ} \mathrm{C}$. Ye et al. (2011) showed that water temperature affects physiological performance of larvae of yellowtail clownfish Amphiprion clarkii. Survival and SGR of larvae of $A$. clarkii increased with the increase of temperature from 23 to $29^{\circ} \mathrm{C}$. Water temperature also influenced with feed ration (FR) and FCR increased with the increase of water temperature from 23 to 29 ${ }^{\circ} \mathrm{C}$.

This investigation has shown that ambient temperature has significant effects on fingerlings growth and food utilization. Water temperatures around $30^{\circ} \mathrm{C}$ yielded the highest outcomes in terms of growth and FCR compared to other thermal treatments evaluated. Results of this study also provide baseline information and establish preliminary limits of water temperature for black pacu fingerling culture under hatchery conditions. However, the growth experiment was performed in small tanks with a small quantity of fish, so the results from the current research can not necessarily be generalized to fish held at higher abundance in outdoor ponds or cages. Furthermore, many other factors such as water quality, experimental methods, feed quality, fish age, or stocking rate, may influence feed intake, growth, etc. Further studies are necessary to better understand black pacu's growth characteristics under different environmental conditions and then to provide reasonable management strategies to the large-scale farming of this fish.

This study has implications regarding possible changes in regional temperatures as well as affecting future aquacultural success. Black pacu aquacultural activities typically occur in temperatures averaging between 26 and $30^{\circ} \mathrm{C}$ (personal observation). The present study demonstrates that the near optimal growth occurred at $\sim 30^{\circ} \mathrm{C}$. Accordingly, a slight 1 to 2 ${ }^{\circ} \mathrm{C}$ increase, as is now in some cases the lower limit of expected global temperature change, would soon exceed the thermal optimum for this species making aquacultural activities less efficient with obvious effects on fish culture efficiency and economical profitability.

\section{BIBLIOGRAFÍA CITADA}

Alcántara, F.B.; Colace, M.B. 2001. Piscicultura, seguridad alimentaria y desarrollo en la carretera Iquitos-Nauta y el río Tigre. Valorando y 
preservando nuestros peces amazónicos. Instituto de Investigaciones de la Amazonía Peruana. Iquitos. Perú. 83p.

Anderson, M.J.; Fast, A.W. 2008. Temperature and feed rate effects on Chinese catfish, Clarias fuscus (Lacepède), growth. Aquaculture Research, 22: 435-442.

Arizcun, M.; López-Albors, O.; Abellán, E.; Ayala, M.D.; Gil, F.; García-Alcázar, A.; Nortes, N.J.; Ramírez-Zarzosa, G. 2002. Efecto de las temperaturas de incubación y de cultivo larvario sobre el crecimiento del músculo blanco del dentón Dentex dentex (Linnaeus, 175). Boletín del Instituto Español de Oceanografía, 18:371 -376.

Ayala, M.D. 1999. Influencia de la temperatura sobre el crecimiento muscular de la lubina, Dicentrarchus labrax L., durante el desarrollo larvario. Tesis doctoral. Facultad Veterinaria. Universidad de Murcia. 222 pp.

Borghetti, J.R.; Canzi, C. 1993. The effect of water temperature and feeding rate on the growth rate of pacu (Piaractus mesopotamicus) raised in cages. Aquaculture, 114(1-2): 93-101.

Campos-Baca, L.; Kohler, C.C. 2005. Aquaculture of Colossoma macropomum and related species in Latin America. American Fisheries Society Symposium, 46: 451-561.

Casado, D.C.P.; Rodríguez, C.L.; Alcántara, F.B; ChuKoo, F. 2009. Evaluación del trigo regional Coix lacryma-jobi (Poaceae) como insumo alimenticio para gamitana Colossoma macropomum. Folia Amazónica, 18(1-2):89-96.

Chu-Koo, F.; Alcántara, F.B. 2009. Cultivo de paiche doméstico. Perspectivas económicas. Pesca Responsable, 57(2): 32-33.

Dabrowski, K.; Rinchard, J.; Ottobre, J.; Alcántara, F.; Padilla, P.; Ciereszko, A.; De Jesus, M.J.; Kohler C.C. 2003. Effect of oxygen saturation in water on reproductive performances of Pacu Piaractus brachypomus. Journal of the World Aquaculture Society, 34: 441-449.

Dañino, P.A.; Nash, R.L.; Chu-Koo, F.; Mori-Pinedo, L. 2011a. Crecimiento, conversión alimenticia y sobrevivencia de paco (Piaractus brachypomus) cultivado en estanques con y sin revestimiento de geomembranas en la Amazonía peruana. In: J. Núñez, F. Chu-Koo, J. Porto, and C.R. GarcíaDávila (eds.). Comunicaciones del II Workshop sobre Biología de las Poblaciones de Peces de la Amazonía y Piscicultura. p.148-154.

Dañino, P.A.; Nash, R.L.; Chu-Koo, F. 2011 b. Rendimiento productivo de la gamitana (Colossoma macropomum) cultivada en estanques con y sin revestimiento de geomembranas en la Amazonía peruana. In: J. Núñez, F. Chu-Koo, J. Porto, and C.R. García-Dávila (eds.). Comunicaciones del II Workshop sobre Biología de las Poblaciones de Peces de la Amazonía y Piscicultura. p.155-161.

Das, T.; Pal, A.K.; Chakrabortyb, S.K.; Manusha, S.M.; Sahua, N.P.; Mukherjee, S.C. 2005. Thermal tolerance, growth and oxygen consumption of Labeo rohita fry (Hamilton, 1822) acclimated to four temperatures. Journal of Thermal Biology, 30: 378-383

De Souza, M.G.; Almeida, O.M.G.; Arruda, L.E.T.; Maciel, J.A.; Raposo, M.C.M.R. 2007. Desempenho e atividade de amilasa em tilapiasdo-nilo submetidas a diferentes temperaturas. Pesquisa Agropecuária Brasileira, 42: 16091615.

Hochachka, P.W.; Somero, G.N. 2002. Biochemical adaptation: mechanisms and process in physiological evolution. Oxford University Press, Oxford.

Jobling, M. 1994. Fish bioenergetics. Chapman \& Hall, London, UK.

Kubitza, F. 2000. Tilápia: tecnologia e planejamento na produção comercial. Jundiaí. 289 pp.

Lochmann, R.; Chen, R.; Chu-Koo, F.W.; Camargo, W.; Kohler, C.C.; Kasper, C. 2009. Effects of carbohydrate-rich alternative feedstuffs on growth, survival, body composition, hematology, and non-specific immune response of black pacu, Colossoma macropomum, and red pacu, Piaractus brachypomus. Journal of the World Aquaculture Society, 40: 33-44.

Miller, T.J.; Crowder, L.B.; Rice, J.A.; Marschall, E.A. 1988. Larval size and recruitment in fishes: toward a conceptual framework. Canadian Journal of Fisheries and Aquatic Sciences, 45: 1657-1670.

Murugaian, P.; Ramamurthy, V.; Karmegam, N. 2008. Protein conversion efficiency of Labeo rohita (Ham.) in different cultural conditions. International Journal of Applied Environmental Sciences, 3: 57-64.

Núñez, R.J. 2009. Domestication of new economically important Amazonian fish species. Cah Agric., 18(2-3): 136-143.

Okamoto, M.H.; Sampaio, L.A.; Maçada, A.P. 2006. Efeito da temperatura sobre o crescimento e a sobrevivência de juvenis da tainha Mugil platanus Günther, 1880. Revista Atlântica, 28: 61-66.

Oyugi, D.O.; Cucherousset, J.; Baker, D.J.; Britton, J.R. 2012. Effects of temperature on the foraging 
and growth rate of juvenile common carp, Cyprinus carpio. Journal of Thermal Biology, 37(1): 89-94.

Pérez-Casanova, J.C.; Lall, S.P.; Gamperl, A.K. 2009. Effect of feed composition and temperature on food consumption, growth and gastric evacuation of juvenile Atlantic cod (Gadus morhua L.) and haddock (Melanogrammus aeglefinus L.). Aquaculture, 294: 228-235

Petry, A.C.; Agostinho, A.A.; Piana, P.A.; Gomes, L.C. 2007. Effects of temperature on prey consumption and growth in mass of juvenile trahira Hoplias aff. malabaricus (Bloch, 1794). Journal of Fish Biology, 70: 1855-1864.

Piedras, S.R.N.; Morães, P.R.R.; Pouey, J.L.O.F. 2004. Crescimento de juvenis de jundiá (Rhamdia quelen), de acordo com a temperatura da água. Boletim do Instituto de Pesca, 30: 177-182.

PRODUCE (Ministerio de la Producción). 2012. Cosecha de recursos hidrobiológicos procedentes de la actividad de acuicultura según ámbito y especie (ene - oct 2011). Boletín Estadístico. http://www.produce.gob.pe/RepositorioAPS/3/jer /ACUISUBMENU01/2011/octubre/05_01.pdf. Accesado el 10 de enero de 2012.
Silva, C.R.; Gomes, L.C.; Brandão, F.R. 2007. Effect of feeding rate and frequency on tambaqui (Colossoma macropomum) growth, production and feeding costs during the first growth phase in cages. Aquaculture, 264(1-4):135-139.

Sogard, S.M.; Olla, B.L. 2002. Contrasts in the capacity and underlying mechanisms for compensatory growth in two pelagic marine fishes. Marine Ecology Progress Series, 243: 165-177.

Sun, L.H.; Chen, H. 2009. Effects of ration and temperature on growth, fecal production, nitrogenous excretion and energy budget of juvenile cobia (Rachycentron canadum). Aquaculture, 292:197-206.

Tello, S. 2011. Programa AQUAREC. Informe de Gestión 2011. Instituto de Investigaciones de la Amazonía Peruana-IIAP. Iquitos, Perú. 43p.

Ye, L.; Yang, S.Y.; Zhua, X.M.; Liu, M.; Lin, J.Y.; Wu, K.C. 2011. Effects of temperature on survival, development, growth and feeding of larvae of Yellowtail clownfish Amphiprion clarkii (Pisces: Perciformes). Acta Ecologica Sinica, 31(5): 241-245. 